\title{
Forest Transition and Its Dynamics in Subtropical Chongqing, China since 1990s
}

\author{
Lingyue $\mathrm{Li}^{1}$, Zhixin $\mathrm{Qi}^{2, *}$ and Teng Zhong ${ }^{3}$ \\ 1 Department of Urban Planning, College of Architecture and Urban Planning, Tongii University, \\ Shanghai 200092, China; lilingyue@tongji.edu.cn \\ 2 Guangdong Provincial Key Laboratory of Urbanization and Geo-simulation, School of Geography and \\ Planning, Sun Yat-sen University, Guangzhou 510275, China \\ 3 Key Laboratory of Virtual Geographic Environment (Ministry of Education), Nanjing Normal University, \\ Nanjing 210023, China; tzhong27@njnu.edu.cn \\ * Correspondence: qizhixin@mail.sysu.edu.cn; Tel.: +86-020-84115833
}

Citation: Li, L.; Qi, Z.; Zhong, T.

Forest Transition and Its Dynamics in Subtropical Chongqing, China since 1990s. Land 2021, 10, 777. https:// doi.org/10.3390/land10080777

Academic Editors: Diane L. Haase, Jeremiah R. Pinto and Owen T. Burney

Received: 18 June 2021

Accepted: 20 July 2021

Published: 23 July 2021

Publisher's Note: MDPI stays neutral with regard to jurisdictional claims in published maps and institutional affiliations.

Copyright: (c) 2021 by the authors. Licensee MDPI, Basel, Switzerland. This article is an open access article distributed under the terms and conditions of the Creative Commons Attribution (CC BY) license (https:// creativecommons.org/licenses/by/ $4.0 /)$.

\begin{abstract}
This research aims to advance our understanding towards forest transition, which is about the shift from net deforestation to net reforestation over a given area during certain period, through a case study of a western city in China from 1990 to 2015. Three main contributions are made to the theory and practice of forest land management. First, this research enriches forest transition theory with a meso-level exploration on forest land change in subtropic Chongqing, which echoes the "U" shape transition rules widely observed in the Euro-American context but was found a time lag of the turning point until 2000s. Second, it intentionally identifies the subtype of forests-the artificial plantation, which is considered influential on performance of forest's carbon sequestration but not paid sufficient attention to. Third, it adds knowledge on forest transition pathway at an intraurban scale through the identified significance degree of forest transition dynamics, which implies that economic development matters but is less important than topography in a mountainous city like Chongqing, and different dimensions of economy impact differently on forest transition.
\end{abstract}

Keywords: forest transition; land use change; characteristics; dynamics; Chongqing; China

\section{Introduction}

Though worldwide deforestation remains alarmingly prominent, its rates have been dropping, and a shift to net reforestation, scholarly termed as forest transition, has been noticed in a number of countries [1-3]. This " $U$ " shape phenomena of forest transition were first noted in early 19th century France, then in the United Kingdom, Switzerland, the United States, Denmark, Portugal, and Japan [4-7]. Theorization of the phenomena thus is primarily grounded in these advanced industrialized, mainly Euro-American countries [8]. Since the 1990s, net reforestation has eminently been observed in Asia, among which China, the industrialization giant successor, is reported to be the country experiencing the fastest growth of forests on earth [9-12]. Though China's rapid forest expansion has caught scholarly attention, research results vary greatly and are sometimes paradoxical [13-15]. For instance, some scholars believe that China is undergoing " $U$ " shape curve in its forest resources [16], others think that the evidences are insufficient and call the U-shaped relation between forest and economy into question [16,17]. Even when admitting the " $U$ " shaped curve, the turning point is also arguable, given the omnifarious statements of, e.g., the 1980s or late 1990s [14,15]. This research views China's forest transitions a heterogeneous landscape that a more nuanced and localized critical examination on the source, flows and spatiotemporal patterns of this large scale, domestic forest transition is in need. This is particularly true in those mountainous, urban-rural coordinated areas where factors related to urbanization and those of natural ones may both produce significant impacts on this transition. 
Remote sensing and geographical information system technology capable of capturing large-range, long-time span change of land-use/land-cover help to display and quantify forest transition across time periods $[18,19]$. Indicators such as annual change rate and Gini coefficients assist to measure the speed and (un)balance of the transition [20-24]. Benefitted from these methods, great many studies have portrayed the general trends of deforestation and reforestation on earth [1], especially in tropical areas $[9,25]$ and found that urban and agricultural expansions were considered the two main processes threatening the loss of forest land [26-28]. Is similar forest transition observed in fast expanded Chinese cities? How this transition is spatially distributed, and why? Given the known knowledge on the net forest gain in recent years, scholars argue for in-depth, multiscale examination over subtle changes of forest land and how these changes are spatially varied in different climate zones especially at intra-urban or intra-regional scale, which is critical for mesoand micro-level forest policy making and localized land administration.

Another significant but often overlooked reality in existing studies is the lack of discrimination of natural forest and planation, the quality of which leads to differentiated ecosystem services, thus influences the performance of forest's carbon sequestration [29]. In places where natural forest loss and plantation expansion simultaneously occur, e.g., Ecuador and Chile, the increase of overall forest cover area is found to had negative effects on carbon storage. In other words, gains of forest from plantations at the cost of natural forest loss do not benefit carbon fixation or reduction [30]. Therefore, research on the overall change of forest cover area alone is not enough to uncover the actual alteration of ecosystem services result from the forest transition. A proper treatment of different forest types, at least distinguishing natural forest and afforestation, would be a starting point consummating forest transition studies and inspiring policy making for improving ecosystem services [31].

Scholars also identified several major, often overlapping, pathways of forest transition. The primary pathway is the typical " $U$ " shape phenomena found in association with socioeconomic development. Scholars report that alongside the increase of income and level of economic development and urbanization, deforestation happens, reaches a peak, then drops, and follows with a gradual reforestation or afforestation $[2,3]$. Another equally important pathway attributable to reforestation is found inherently related to the demand for forest-based eco-services and values of forest products, that is, forest scarcity results in reforestation [32-34]. Other pathways are found driven by state-led reforestation policies, globalization, and land use intensification of smallholder agriculture but are sensitive to political, geographical, and local socioeconomic contexts [34,35]. Among the various factors influencing change of forest land, forestry output value is considered associated with both forest scarcity and economic development $[5,14,36]$. Growth of GDP, urbanization of rural population and road density as indicators able to reflect level of economic development and urbanization are found positively related to forest expansion [37-39]. Increase of grain productivity per square kilometer as an indicator reflects not only economic development but also land use intensification. Topographical and hydrographical indicators such as slope and distance to natural rivers well capture characteristics of local environment [40,41]. To what extent these indicators influence forest transition in a local context deserves critical examination.

Endeavoring for constructing national forest city under the discourse of urban-rural coordination, Chongqing, located in southwest China, is intriguing to echo the three research objectives indicated above given its rapid economic growth, forceful reforestation policies and vast ecological conservation areas: (1) to unveil an intra-metropolitan source, flows and spatiotemporal patterns of forest transition and identify whether a U-shaped curve, observed in the Euro-American context, exists in the study area; (2) to give an eye on the subtype of forests-the artificial plantation, which is considered influential on performance of forest's carbon sequestration; and (3) to analyze the significance degree of forest transition dynamics, especially the diverse relation between the change of forest land and economic development. The following then the lists the method and result of 
forest land change in Chongqing metropolis, so as to enrich an urban-level understanding towards forest transition in Chinese context.

\section{Research Method}

\subsection{Site for Study}

Chongqing $\left(105^{\circ} 11^{\prime}-110^{\circ} 11^{\prime} \mathrm{E}, 28^{\circ} 10^{\prime}-32^{\circ} 13^{\prime} \mathrm{N}\right)$ locates at the junction of the QinghaiTibet Plateau and the plains of the middle and lower reaches of the Yangtze River (Figure 1), covering an area of 82,402 sq. km. As an important ecological barrier in the Yangtze River Basin and a national strategic water resource reserve, it shoulders the responsibility to guarantee ecological security in the Three Gorges Reservoir area and the middle and lower reaches of the Yangtze River, in which forest plays an irreplaceable role. Since the catastrophic floods occurred in the Yangtze River Basin in 1990s, ecological security has been given priority in local agenda and Chongqing municipal government has launched a series of forest ecological projects to protect its natural environment.

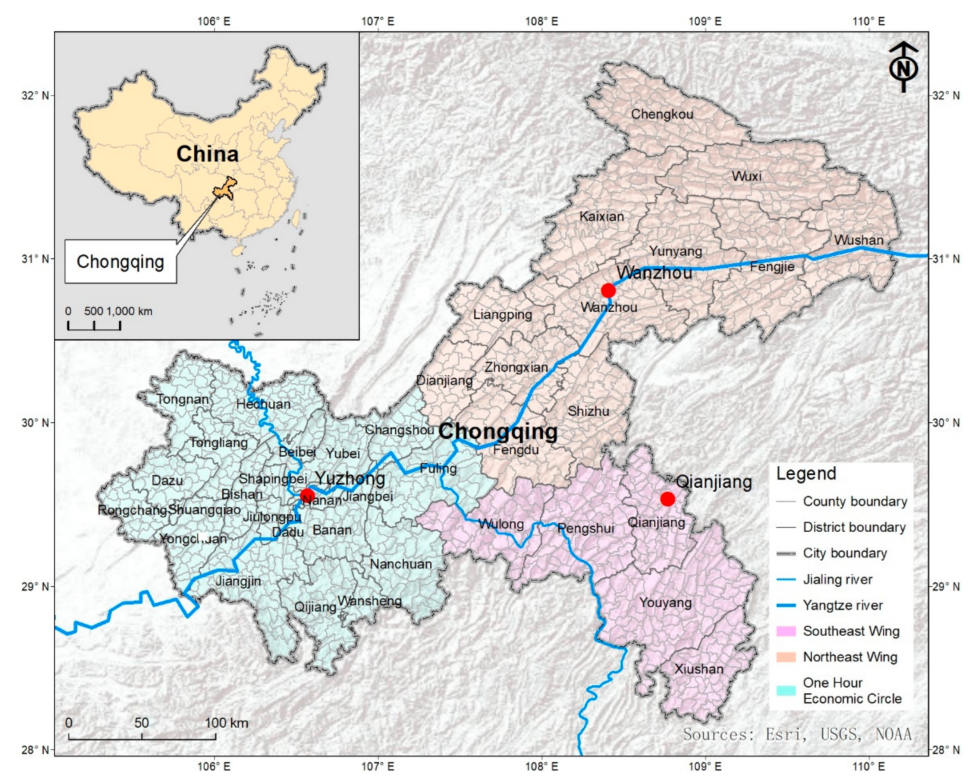

Figure 1. Location and spatial structure of Chongqing; Source: edited by authors.

Complex in topography, Chongqing encompasses vast territory, dominated by mountains and hills (accounting for $75.8 \%$ and $18.2 \%$ of total area, respectively) with rich natural vegetations. Its unique geographical milieu and subtropical climate zone location provide beneficiary conditions for diverse forest development, e.g., subtropical evergreen broad-leaved forest, deciduous broadleaf forest, mixed forests of the former two and warm coniferous forest, etc., producing prominent effects on ecological conservation. Within Chongqing's jurisdiction, the main tree species include mason pine, fir, cypress, oak, birch and poplar, etc. that are widespread planted in Mountain Wuling, Jinyun, Simian, and Jinfo. Being one of China's largest metropolises, Chongqing entrusted with demonstration task of urban-rural coordination is characterized by a "One Circle, Two Wings" metropolitan structure, offering the spatial framework for analysis of forest transition. In this structure, One Circle refers to the economically advanced urban functional core/development area while Two Wings indicate the northeast wing of ecological conservation development area and the southeast wing of ecological protection area (Figure 1). In this figure, the boundaries with dark gray refer to districts or counties at the bureau level (tingju ji) and the boundaries with light gray refer to towns, villages or streets within the districts or counties. There are 39 districts/counties and roughly more than 1000 villages/towns/streets in Chongqing. 


\subsection{Data Analysis}

\subsubsection{Forest Land Data}

Multi-source data are deployed to reveal the spatiotemporal patterns of forest land change. The primary source is China's Land-Use/Cover Dataset (CLUD) collating remoting sensing image encompassing (non)forest classification at 30-m resolution in 1990, 2000, 2010, and 2015 in Chongqing [42]. The CLUD was gathered from multiple sources of Landsat Multispectral Scanner (MSS), Thematic Mapper (TM), Enhanced Thematic Mapper Plus (ETM+), and Operational Land Imager (OLI), combined with multispectral data from the Huanjing-1 satellite (HJ-1) [42]. The raw data contain six primary-level classifications-farmland, forest, grassland, waters, built-up land, and unused land, so that the source and flow of forest change can be traced. Here, the forest land is inclusive of a broad sense of all standing forests, e.g., shrub and open forest, etc. (Figure 2). Moreover, statistical yearbooks are consulted to collate annual forest data and socioeconomic data that is influential on forest transition. To further obtain data of the sub-types of forest transition, e.g., the artificial planation, this research consults the Yearbook Sharing Platform (www.yearbookchina.com, accessed on 20 May, 2021) and search words of "Chongqing" and "artificial planation (rengong zaolin)" in combination. As Chongqing was upgraded to a metropolis directly under the administration of central government in 1997, the available municipal statistical data were after 1997. Three types of statistics documents are found reporting the artificial planation area at provincial level: China Forestry Statistical Yearbook (zhongguo linye tongji nianjian), China Statistical Yearbook on Environment (zhongguo huanjing tongji nianjian), and Compilation of Agricultural Statistics in 30 Years of Reform and Opening (gaige kaifang sanshinian nongye tongji ziliao huibian). This research takes China Statistical Yearbook on Environment to collate yearly artificial planation data and checks data accuracy with the other two statistics documents.
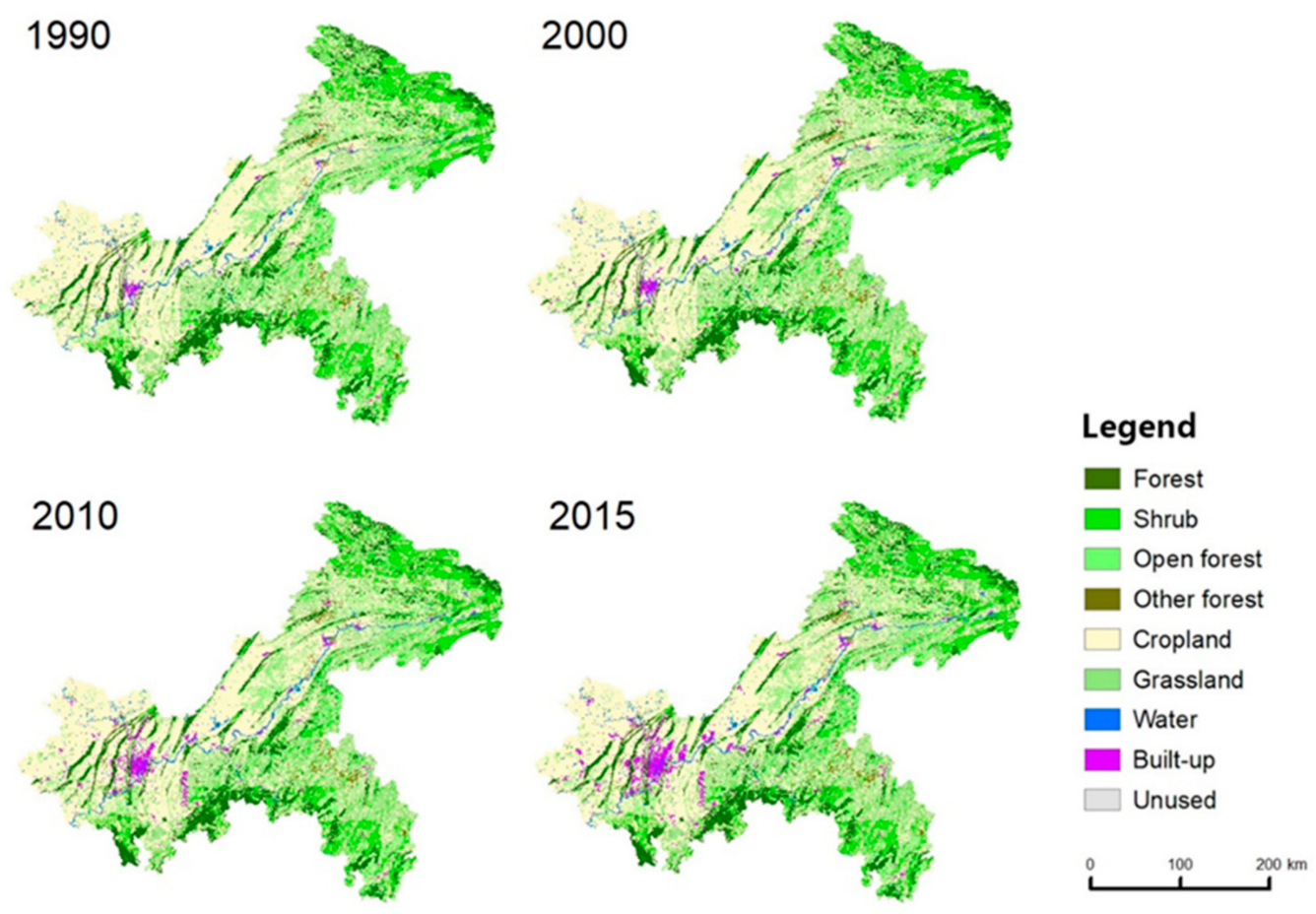

Figure 2. Land use and forest land maps in Chongqing (1990, 2000, 2010, 2015); Source: edited by authors.

\subsubsection{Characterizing Forest Transition}

An exploratory, progressive approach is applied to unravel the change of forest land and forest resources in Chongqing. To characterize the intra-metropolitan patterns of 
forest transition, a multiscale perspective is adopted in line with Chongqing's multi-level spatial layout. At the metropolitan level, sources and flow of forest display the land use impetus of forest transition. The transitioned forest cover area from/to other land use type divided by its net increased/decreased area eliminating the impact of area size manages to showcase the conversion between forest and other land use. This research uses $F C_{l o s s}(i)$, jo represent the former and $F C_{\text {gain } i,(j)}$ to indicate the latter. In specific, $F C_{\operatorname{loss}(i), j}$ represents the proportion of the converted forest cover area (in line $i$ ) to another type of land use in column $j$ to the total loss of forest cover in the same period; $F C_{g a i n} i,(j)$ indicates the ratio of converted area from other types of land use in line $i$ to forest cover in column $j$ to total increased forest area. Both $F C_{l o s s}(i), j$ and $F C_{\text {gain } i,(j)}$ are contribution rates of land use transition out of or to forest. $F C N_{\text {gain }} i, j$ refers to the net increase rate of forest (in line $i$ ) from land use type j. $F C_{. i}$ and $F C_{i}$, are the total areas of gained/lost of forest cover from/to other areas in column $i$ and line $i$, respectively.

Preliminary observation suggests that gains of forest cover evidently happened after the year 2000 in Chongqing, before that, the area of forest cover declined in general and the outbreak of 1998 well-known basin-wide catastrophic flood had raised the significance of forest-based soil and water conservation. Therefore, annual data related to forest resources, e.g., the artificial planation, total standing forest stock, stock volume of forest, and ratio of forest coverage after 2000 are identified to provide additional information for this study.

To move forward to unravel how the loss and gains of forest cover are spatially distributed and variated, this research links the spatial database of Chongqing containing both district/county-level and village/town-level spatial units with forest cover data with coordinates. For all the time periods, statistical spatial units are based on administrative division and adjustment after the city was upgraded as a municipality directly under the administration of the central government. As the change of forest land is minimal compared with the absolute value of forest land area, this research only maps the spatial distribution of forest land in 2015 and calculate Gini coefficient and coefficient of variation accordingly, which is sufficient to represent the spatial distribution and concentration degree in other years. The coefficients of variation $(\mathrm{CV})$ capturing the extent of variability of change rate of forest cover and the Gini coefficients measuring the degree of spatial concentration of change rate of forest cover are calculated to quantify the spatial variance of loss/growth rate of forest cover.

\subsubsection{Analyzing Forest Transition Dynamics}

A valid land administration and conducive policy making on forest development necessitate the identification and analysis of dynamics of land use transition. While various factors are found related to forest land change, for instance, development and natural geographical factors such as GDP, demographic change, altitude and slope, their influences are discrepant under different natural economic milieu and local context [43-45], which deserves further research. In this research, data of the ratio of forest land to total land area in each district or county in 2000, 2010, and 2015, obtained through remote sensing and GIS technology, are aggregated as dependent variables. Seven independent variables are sought out informed by review and considering data availability (Table 1). Variables related to hydrography and topography include distance to two main rivers in Chongqing, the Yangtze and Jialing River, and the mean slope in each district or county. Data of the distance to rivers are measured through GIS software, referring to the vertical distance (shortest distance) from the administrative center of the chosen city to either Yangtze or Jialing River. Data of the mean slope are obtained from a topographical research about Chongqing [41]. All the following data are obtained from Chongqing Statistical Yearbooks based on the administrative division: variables indicating level of economic development include GDP per square kilometer and forestry output value; road density represents the intensity of construction activities; rural employed population and grain yield efficiency exemplify the level of rural development. 
Table 1. Dependent and independent variables.

\begin{tabular}{|c|c|c|c|c|c|c|c|}
\hline & Description & Units & Min & Max & Median & Mean & SD \\
\hline \multicolumn{8}{|c|}{ Dependent Variables-Forest Land (Ratio) } \\
\hline \multirow{2}{*}{\multicolumn{2}{|c|}{$\begin{array}{l}1 \text { Ratio of forest land } \\
2 \text { Forest land area }\end{array}$}} & $\%$ & 0.43 & 64.31 & 27.13 & 30.37 & 17.14 \\
\hline & & Sq.km & 0.18 & 2390.40 & 444.76 & 773.82 & 739.89 \\
\hline \multicolumn{8}{|c|}{ Independent Variables } \\
\hline Variable 1 & Proximity to rivers & $\mathrm{km}$ & 0.18 & 113.11 & 7.76 & 24.39 & 26.22 \\
\hline Variable 2 & Mean slope & - & 3.70 & 28.10 & 11.26 & 12.94 & 6.13 \\
\hline Variable 3 & GDP intensity & 10,000 Yuan/sq.km & 113.27 & $226,783.29$ & 703.93 & 6429.77 & 25107.65 \\
\hline Variable 4 & Forestry output value & 10,000 Yuan & 0 & $40,278.27$ & 6399.00 & 9715.68 & 9234.01 \\
\hline Variable 5 & Road network density & km/sq. km & 0 & 3.88 & 1.54 & 1.42 & 0.74 \\
\hline Variable 6 & Rural employed population & 10,000 persons & 0 & 82.42 & 34.90 & 33.94 & 19.80 \\
\hline Variable 7 & Grain yield efficiency & ton/sq. km & 0 & 568.29 & 294.63 & 283.34 & 113.86 \\
\hline
\end{tabular}

Source: edited by authors.

The random forest regression is used to capture the degree of significance of each factor in forest land transition. Random forests are an ensemble learning method that constructs a multitude of decision trees for classification or regression. The average prediction of the individual trees is returned for regression. Less expensive than other machine learning methods such as Artificial Intelligence Network [46-48], random forest (RF) is a treebased algorithm that is mild demanding on quantities of data sources and can compute significance degree of factors under data constraints. Variable importance evaluation with random forests is made by out-of-bag $(\mathrm{OOB})$ error, which is the mean prediction error on each variable using only the trees that did not involve that variable. Two measures are commonly used for the $\mathrm{OOB}$ error. One is the percent increase in mean squared error (\%IncMSE) as a result of a variable being permuted. The other is the total decrease in node impurities (IncNodePurity) from splitting on the variable. The IncNodePurity is measured by residual sum of squares for regression tasks.

\section{Results and Discussions}

\subsection{Characteristics of Forest Transition in Chongqing}

The general source and flow of forest transition are calculated and summarized in Table 2. From 1990 to 2015, forest land had first decreased from $30,661 \mathrm{~km}^{2}$ to $30,630 \mathrm{~km}^{2}$ during the first 10 years, then increased from $30,630 \mathrm{~km}^{2}$ to $31,063 \mathrm{~km}^{2}$ during the latter 15 years. Though such general trend has experienced fluctuation amidst the process, e.g., area of forest land indeed reached the peak to $31,166 \mathrm{~km}^{2}$ in 2010 then dropped thereafter according to the remote sensing data; this does not prevent forest land change in Chongqing from echoing the " $U$ " shape rules in forest transition theory at metropolitan scale. The Three Gorges project and the rapid expansion of urban area have once threatened the overall forest land use in Chongqing, especially before 2000. Forest issues have earned great attentions since the 1998 well-known basin-wide catastrophic flood and reforestation accelerated thereafter. According to Table 2, during the transition peak of forest from 2000 to 2010, farmland and grassland are two major sources, substantially contributing $323.906 \mathrm{~km}^{2}$ and $297.825 \mathrm{~km}^{2}$ to the transition of forest land, suggesting prominent effects of the policy of Grain for Green. In the meanwhile, conversion between built-up land, waters and forests are comparatively insignificant, only $35.143 \mathrm{~km}^{2}$ and $45.110 \mathrm{~km}^{2}$ forest land was converted to waters and built-up land during the fast urbanization.

A further exploration on annual forest transition on the right side of the " $U$ " shape in post 2000 suggests a gradualist gain but differed increasing rates of forest land and forest area, that is, the latter of standing trees excluding shrub and sparse forest land has gained more area size and grew faster than the former (Figure 3). Forest area is different from forest land in that the former refers to forest land with a canopy closure of 0.2 or above, or forest belt with a crown width of $10 \mathrm{~m}$ or above, which include both natural or artificial 
coniferous forests, broad-leaved forests, mixed coniferous, and broad-leaved forests but exclude shrub forest land and sparse forest land. In 2001, forest area was only $17,790 \mathrm{~km}^{2}$, in 2010, the number has reached 30,490 $\mathrm{km}^{2}$. Meanwhile, data from the China Statistical Yearbook on Environment suggest that substantial artificial plantation were made in this period. This is particularly true in the year 2003 with the peak of $3314 \mathrm{~km}^{2}$ plantation area, followed by plantation area of $1732 \mathrm{~km}^{2}$ in 2010 and $1548 \mathrm{~km}^{2}$ in 2002. As annual increase of forest land and forest area is no more than $4583 \mathrm{~km}^{2}$, it can be reasonably assumed that considerable increase of overall forest land and forest area comes from the artificial plantation and natural forests may have experienced loss in the same period. This partly explains why carbon emission remains going up despite of the increase of forest cover areas in the city. It also raises the question of the quality of reforestation in Chongqing. That is, whether the increase of overall forest land manages to provide better ecosystem services, and thus improve the level of carbon sequestration and benefit carbon fixation and reduction. Clarification of the question is important as in places such as Ecuador and Chile, gains of forest from plantation at the cost of natural forest loss have already been found negatively related to carbon storage [30].

Table 2. Flow rates of forest land use change in Chongqing during 1990-2000, 2000-2010, and 2010-2015 (km²).

\begin{tabular}{|c|c|c|c|c|c|c|c|c|}
\hline Period & Flow of Con & rsion & Total & Farmland & Grassland & Waters & Built-Up Land & Unused Land \\
\hline \multirow{6}{*}{ 1990-2000 } & \multirow{2}{*}{ Conversion to forest } & Value $\left(\mathrm{km}^{2}\right)$ & 173.169 & 6.151 & 166.586 & 0.432 & 0.000 & 0.000 \\
\hline & & $F C_{\text {gain } i,(j)}(\%)$ & 100.000 & 3.552 & 96.198 & 0.249 & 0.000 & 0.000 \\
\hline & \multirow{2}{*}{ Conversion from forest } & Value $\left(\mathrm{km}^{2}\right)$ & 202.896 & 22.739 & 169.141 & 0.011 & 11.006 & 0.000 \\
\hline & & $F C_{\text {loss }(i), j}(\%)$ & 100.000 & 11.207 & 83.363 & 0.005 & 5.424 & 0.000 \\
\hline & \multirow{2}{*}{ Net conversion } & Value $\left(\mathrm{km}^{2}\right)$ & -29.727 & -16.588 & -2.555 & 0.421 & -11.006 & 0.000 \\
\hline & & $F C N_{\text {gain } i, j}(\%)$ & 100.000 & -55.801 & -8.594 & 1.416 & -37.022 & 0.000 \\
\hline \multirow{6}{*}{ 2000-2010 } & \multirow{2}{*}{ Conversion to forest } & Value $\left(\mathrm{km}^{2}\right)$ & 686.148 & 361.727 & 323.585 & 0.305 & 0.302 & 0.230 \\
\hline & & $F C_{\text {gain } i,(j)}(\%)$ & 100.000 & 52.718 & 47.160 & 0.044 & 0.044 & 0.034 \\
\hline & \multirow{2}{*}{ Conversion from forest } & Value $\left(\mathrm{km}^{2}\right)$ & 144.439 & 37.821 & 25.760 & 35.448 & 45.411 & 0.000 \\
\hline & & $F C_{\text {loss }(i), j}(\%)$ & 100.000 & 26.185 & 17.834 & 24.541 & 31.440 & 0.000 \\
\hline & \multirow{2}{*}{ Net conversion } & Value $\left(\mathrm{km}^{2}\right)$ & 541.709 & 323.906 & 297.825 & -35.143 & -45.110 & 0.230 \\
\hline & & $F C N_{\text {gain } i, j}(\%)$ & 100.000 & 59.793 & 54.979 & -6.487 & -8.327 & 0.042 \\
\hline \multirow{6}{*}{ 2010-2015 } & \multirow{2}{*}{ Conversion to forest } & Value $\left(\mathrm{km}^{2}\right)$ & 0.030 & 0.000 & 0.030 & 0.000 & 0.000 & 0.000 \\
\hline & & $F C_{\text {gain } i,(j)}(\%)$ & 100.000 & 0.000 & 100.000 & 0.000 & 0.000 & 0.000 \\
\hline & \multirow{2}{*}{ Conversion from forest } & Value $\left(\mathrm{km}^{2}\right)$ & 103.620 & 0.005 & 3.031 & 17.494 & 83.089 & 0.000 \\
\hline & & $F C_{\text {loss }(i), j}(\%)$ & 100.000 & 0.005 & 2.925 & 16.88. & 80.186 & 0.000 \\
\hline & \multirow{2}{*}{ Net conversion } & Value $\left(\mathrm{km}^{2}\right)$ & -103.589 & -0.005 & -3.001 & -17.494 & -83.089 & 0.000 \\
\hline & & $F C N_{\text {gain } i, j}(\%)$ & 100.000 & -0.005 & -2.897 & -16.888 & -80.210 & 0.000 \\
\hline
\end{tabular}

Source: edited by authors.

Figure 4 indicates a hollowing pattern of forest land in the city center of the nine districts and reveals that most of the forests are in the two wings area, and the farther away from city center, the larger the forest land area. The southeast wings generally owns more forest land than the northeast wings and are contiguous to the edge of the one-hour economic circle. At district/county scale, Chengkou, Wuxi, and Fengjie in the southeast wings and Youyang in the northeast wing have the largest forest land. At the village/town scale, apart from the aforementioned districts, Nanchuan, Wulong, Fengdu, and Qijiang also have many towns and villages owning large forest land. The spatial concentration degree of forest land area (0.522) is generally higher than that of the ratio of forest land to total area (0.321) at the district/county level as measured by Gini coefficient (Figure 5). The result indicates a mild dispersed spatial patterns of forest land distribution. This mild dispersion, however, does not mean a spatial balance of forest distribution. As the as- 
tonishingly high values of coefficient of variations calculated at the district/county scale suggest, spatial distribution of forest land is quite imbalance with all CVs surpassing 1.03 throughout 1990 to 2010. This is also clearly indicated in the change rate of forest land that shows a distinctive differed forest land change in the "one hour, two wings" spatial structure (Figure 6). The year 2000 turns to be the watershed of forest transition. Forest land generally lost during the period of 1990 and 2000 and the loss rate was relatively evenly distributed across the metropolis. The decrease turned around after 2000 that the two wings, especially in its middle section such as Shizhu, Dianjiang, Pengshui, etc., have experienced substantial increase of forest land.

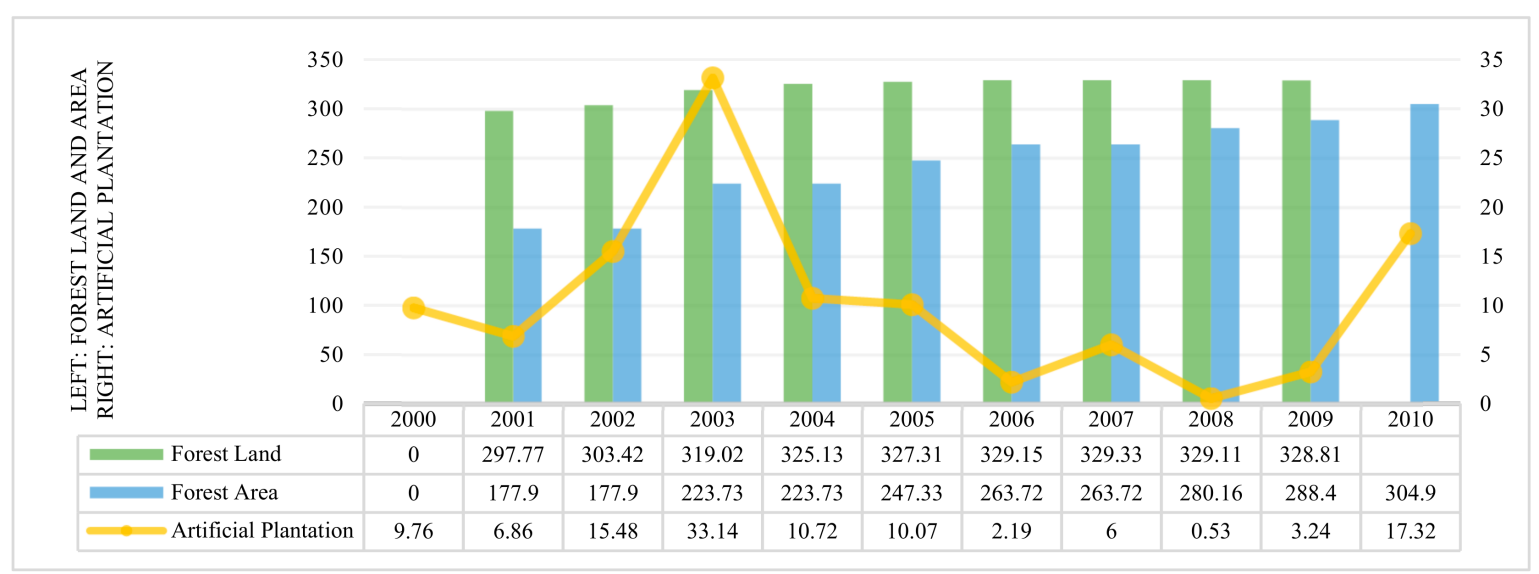

Figure 3. Annual forest change in Chongqing (2000-2010); Source: multiple statistical yearbooks.

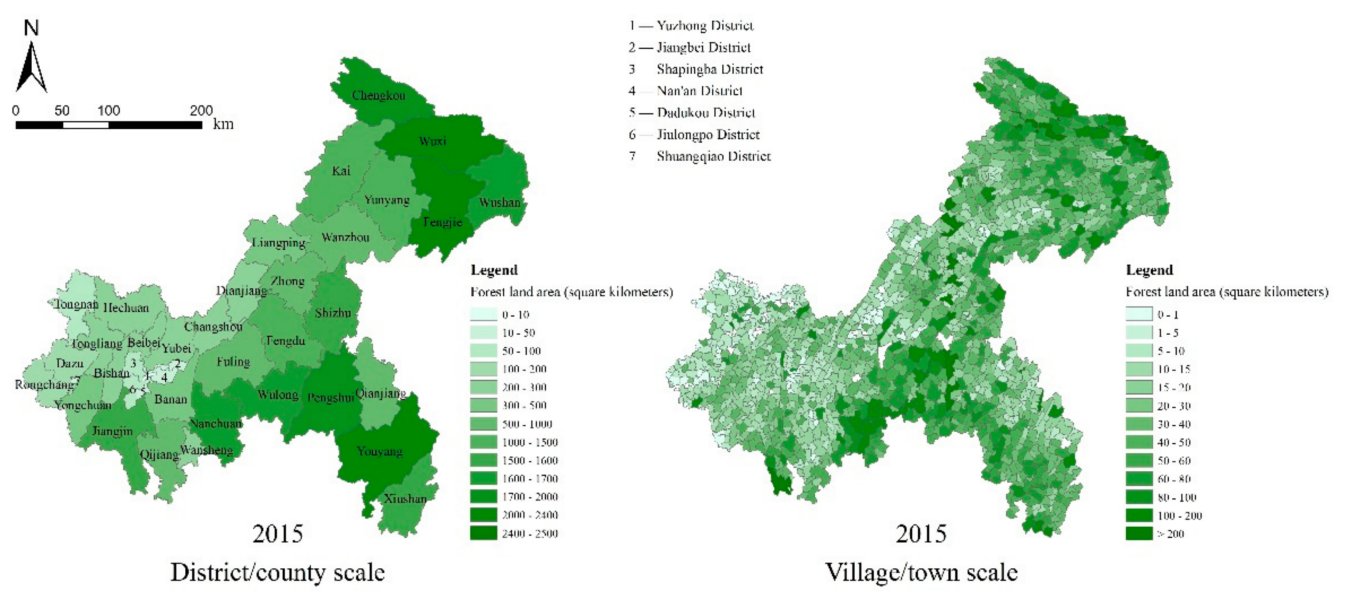

Figure 4. Spatial patterns of forest land area rate at district/county (left) and village/town (right) level; Source: edited by authors. 

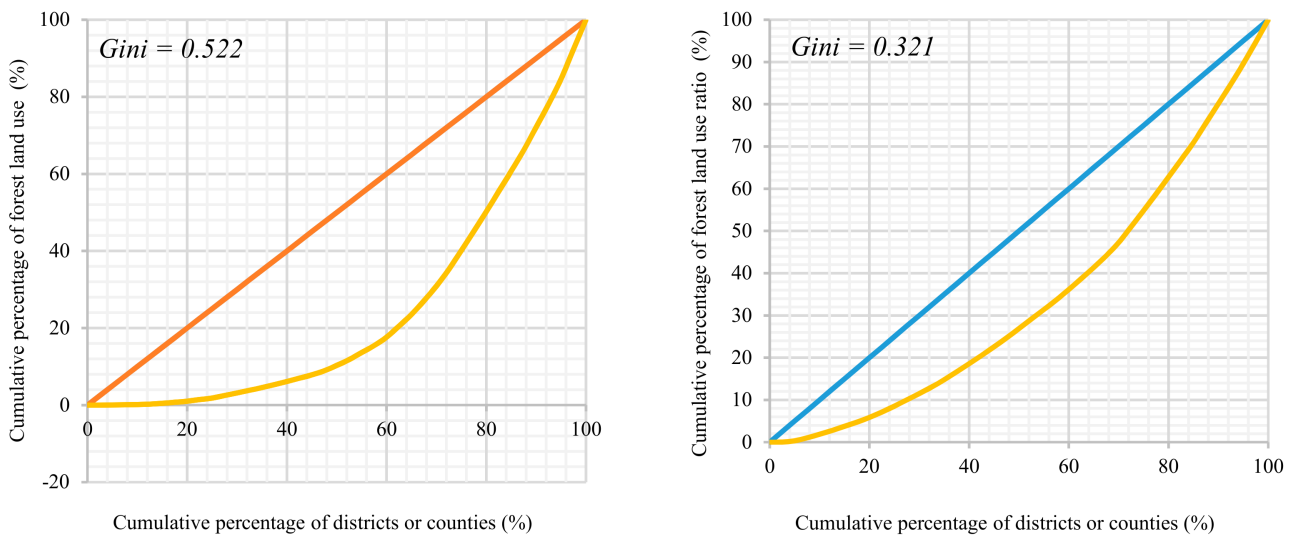

Figure 5. The Lorenz Curve of forest land and its ratio to total land area in 2015; Source: edited by authors.
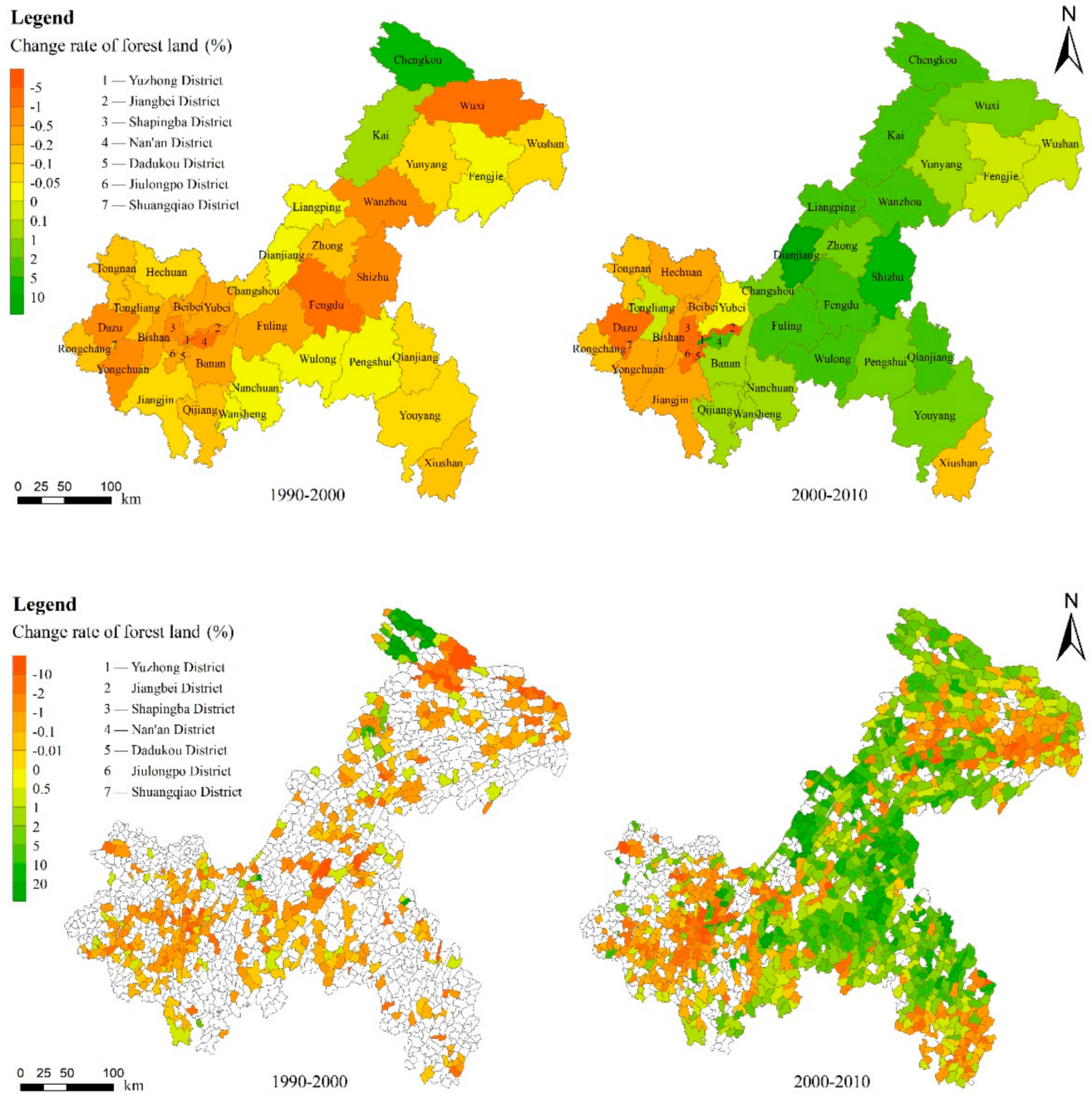

Figure 6. Spatiotemporal patterns of forest land change rate at district/county (up) and town/village (down) level in Chongqing (1990-2010); Source: edited by authors. 


\subsection{The Significance Degree of Forest Transition Factors in Chongqing}

Results of multiple linear regression (MLR) and random forest (RF) are shown in Table 3 and Figure 7. In both two models, mean slope, GDP per square kilometer, rural employed population, and grain yield efficiency are significantly related to ratio of forest land. Topographical factor, as reflected by mean slope, is overwhelmingly significant given its least $p$-value in MLR and greatest value in RF. GDP per square kilometer ranks 2/7 in $\mathrm{RF}$, implying that the level of economy matters for the gain of forest land, which echoes the economic development pathway of forest transition. However, obviously, economy is not as important as topography in the case of Chongqing. In other words, the function of economy in the right side of the " $U$ " shaped curve of forest transition is limited in Chongqing. This is also reflected in the results of forestry output value which, though is considered significant in forest transition upon its association with both forest scarcity and economic development $[5,14,36]$, is proved less so in this research.

Table 3. Results by multiple linear regression and random forest.

\begin{tabular}{|c|c|c|c|c|c|}
\hline Method & \multicolumn{3}{|c|}{ Multiple Linear Regression } & \multicolumn{2}{|c|}{ Random Forest } \\
\hline Dependent Variables & \multicolumn{3}{|c|}{ Ratio of Forest Land } & \multicolumn{2}{|c|}{ Ratio of Forest Land } \\
\hline $\begin{array}{ll}\text { Variables } & \text { Results } \\
\end{array}$ & Coeff. & s.e. & t Stat & IncMSE & IncNode Purity \\
\hline Proximity to rivers & -0.118 & 0.061 & -1.925 & 0.2111 & 0.5791 \\
\hline Mean Slope & $0.812 * * *$ & 0.063 & 12.921 & 0.4283 & 2.7930 \\
\hline GDP per sq.km & $-0.271 * *$ & 0.099 & -2.723 & 0.3533 & 2.3066 \\
\hline Forest output value & 0.041 & 0.066 & 0.616 & 0.1405 & 0.6392 \\
\hline Road network density & -0.116 & 0.079 & -1.483 & 0.0727 & 0.5817 \\
\hline Rural employed population & $-0.353 * * *$ & 0.075 & -4.693 & 0.2148 & 0.6874 \\
\hline Grain yield efficiency & $0.507^{* * *}$ & 0.082 & 6.216 & 0.2348 & 0.7607 \\
\hline R Square & & 0.7378 & & & \\
\hline$\%$ Var explained & & & & & .8466 \\
\hline
\end{tabular}

Note: For multiple linear regression, ${ }^{*} p<0.05,{ }^{* *} p<0.01,{ }^{* * *} p<0.001$, intercept is the mean for the response when all the variables value $0, \mathrm{R}$ square assesses the goodness-of-fit for multiple linear regression; \% Var explained in random forest is similar to $\mathrm{R}$ square in multiple linear regression.

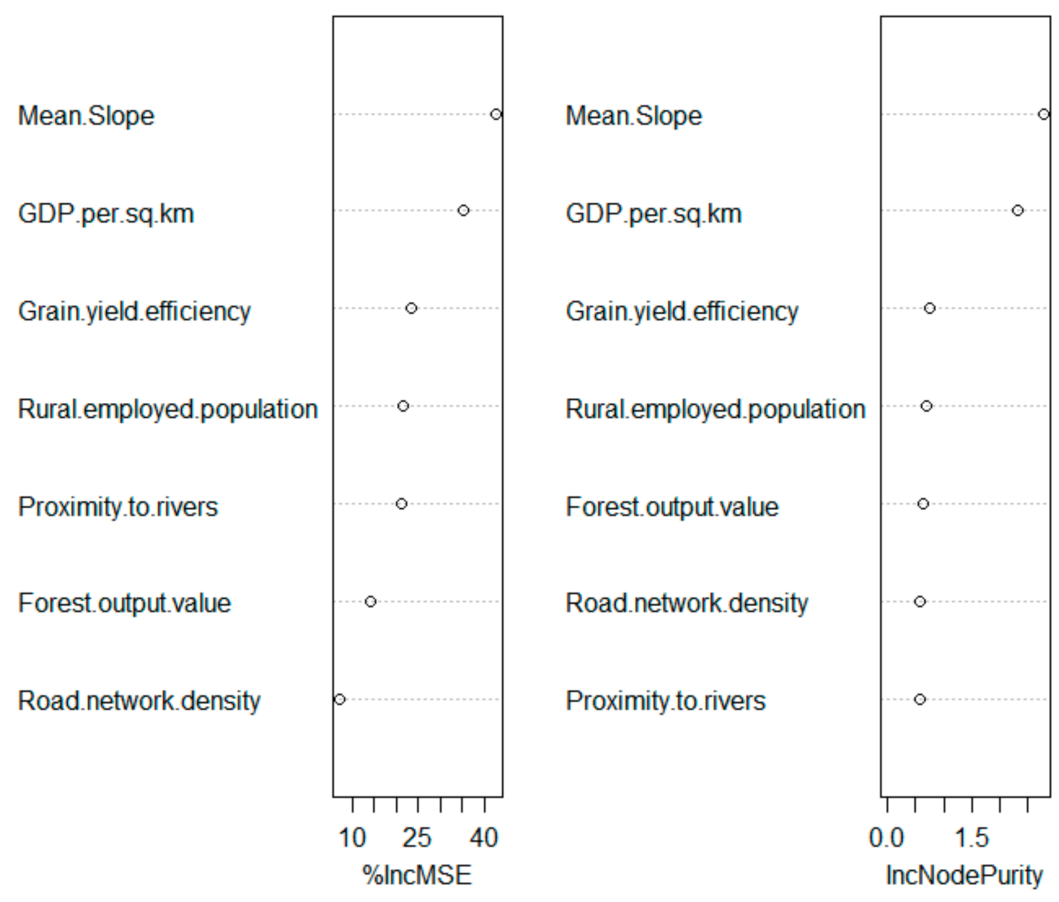

Figure 7. Random Forest result for urban-rural factors and ratio of forest land in Chongqing (increased importance from bottom to top). 
In the economic development pathway, there are normally two major mechanisms assuming to be able to promote the growth of forest land [32]. First, economic growth directly pushes up the price increase of forest products, thus increasing the value of forests. As forest land is characterized by complicated topography and hard to implement mechanized plantation, such increase of forestry output value often leads to the rise of forest land rent price. This is quite different from farmland, which is often situated in flat areas and is prone to achieve mechanized plantation. Improved production efficiency could prevent the rent price of farmland from increasing, when rise of rent price of forest surpasses that of farmland and grass, transition to forest land happens under market regulation [37]. Here, the increase of forestry output value can be viewed as a constituent factor of both economic development and forest scarcity pathways. Reduction of forests (either results from agricultural or urban expansion) leads to shortage of forest products and decreased function of ecosystem service, but human's needs for forest service is inelastic. In a normal market ${ }^{1}$, the price of forest products will go up under this shortage, thus increase the forestry output value. Yet, in this research, significance of forestry output value is not so prominent (with $p$-value surpassed 0.05 in MLR and rank 6/7 in terms of \%IncMSE and 5/8 in terms of IncNodePurity in RF), indicating that increase of forest land through market mechanism did not work well in rural mountainous city. Second, development of economy increases non-agricultural job opportunities thus leads to rural urbanization. Non-agricultural sectors absorbed surplus rural labor force and indirectly propelled higher production efficiency in agricultural sectors. This urbanization-driven increase of forest land through seems work well in this case as significances of agricultural employees (rank 4/7 in its relation to the ratio of forest land in RF) and grain production efficiency (rank 3/7 in its relation to ratio of forest land in RF) follow right after mean slope and GDP per square kilometer and the $p$-values of both are less than 0.001 in MLR. Assuredly, these two factors are not only related to economic development pathway but also part of land use intensification pathway of forest transition.

Distance to rivers (Yangtze and Jialing Rivers in this research) (rank 5/7 and $7 / 7$ in its relation to ratio of forest land in RF) is faintly significant but as its $p$-value almost approaches 0.05 in MLR, its role in forest land change cannot be overlooked. Like many other waterfront cities, Chongqing's initial human settlements developed along the two rivers where frequent commercial and trade activities brought prosperity to the surrounding area. This is especially true for the traditional main city area of Chongqing where the closer to the two main rivers, the higher the production, commerce, leisure and residence densities are. Road network density (rank $7 / 7$ and 6/7 in its relation to ratio of forest land in RF) exemplifying intensity of construction is the least important factor given its rank and $p$-value in both results. This well echoes the identified sources and flows of forest land in Table 2 that conversions between construction land and forest land are quite small compared with those happened between farmland, grass and forests. In other words, accessibility to rivers (river economy) is more to do with forest land change than that to road (road economy).

\section{Conclusions}

This research deals with the paucity of in-depth, multiscale studies on forest transition at intra-urban scale through a case research in a subtropical metropolis, Chongqing, China, since the 1990s to actualize the three objectives. First, it finds that the general trends of forest land change in Chongqing have echoed the " $U$ " shaped curve of forest transition observed in Euro-American countries. Yet, the turning point happens around 2000, roughly in line with the national forest protective measures, e.g., Natural Forest Protection Project (launched in 2000), Grain for Green Program (launched in 1999), and Key Shelterbelt Development Programs along the Yangtze River (launched in 1989 and completed the first phase of the project in 2000) [49-51]. Second, it pays attention to natural forest loss and afforestation during the year 2000-2010 and unveils the truth that the overall increase of forest land in Chongqing is mainly contributed by afforestation while natural forests have 
continued loss since 1990s. Third, findings of dynamics of forest land change generally correspond the economic development pathway of forest transition at the meso-urban scale, but topography as reflected by mean slope is the overwhelmingly important factor in mountainous Chongqing. Instead of treating economic development as a factor solely reflected by GDP, this research looks into its different dimensions through identifying how variables such as rural employed population, grain yield efficiency, and forestry output value are related to economy, unveiling a variance of relations between forest land change and economy. The reform of forest property rights and citizen's demand for forest protection also do favor to forest land increase, which deserve furtherance research.

Author Contributions: Conceptualization, L.L.; methodology, L.L. and Z.Q.; formal analysis, L.L.; data curation, Z.Q. and L.L.; writing — original draft preparation, L.L.; writing - review and editing, L.L., Z.Q., T.Z.; visualization, L.L. and Z.Q.; supervision, L.L.; funding acquisition, Z.Q. All authors have read and agreed to the published version of the manuscript.

Funding: This research has been supported by the National Key R\&D Program of China [Grant No. 2017YFA0604403] and National Science Foundation of China [Grant Number 51808391].

Institutional Review Board Statement: Not applicable.

Informed Consent Statement: Not applicable.

Data Availability Statement: Not applicable.

Conflicts of Interest: The authors declare no conflict of interest.

\section{Notes}

1 Noteworthy, if a market is highly controlled, things would be different. For instance, before the market reform, shortage of forest products did not lead to the price increase of forest products or forestry output value under China's planned economy.

\section{References}

1. Meyfroidt, P.; Lambin, E.F. Global forest transition: Prospects for an end to deforestation. Annu. Rev. Environ. Resour. 2011, 36, 343-371. [CrossRef]

2. Mather, A.S.; Needle, C. The forest transition: A theoretical basis. Area 1998, 30, 117-124. [CrossRef]

3. Grainger, A. The forest transition: An alternative approach. Area 1995, 27, 242-251.

4. Drummond, M.A.; Loveland, T.R. Land-use pressure and a transition to forest-cover loss in the eastern United States. BioScience 2010, 60, 286-298. [CrossRef]

5. Mather, A.S.; Fairbairn, J.; Needle, C.L. The course and drivers of the forest transition: The case of France. J. Rural Stud. 1999, 15, 65-90. [CrossRef]

6. Yeo, I.-Y.; Huang, C. Revisiting the forest transition theory with historical records and geospatial data: A case study from Mississippi (USA). Land Use Policy 2013, 32, 1-13. [CrossRef]

7. Foster, D.R.; Motzkin, G.; Slater, B. Land-use history as long-term broad-scale disturbance: Regional forest dynamics in central New England. Ecosystems 1998, 1, 96-119. [CrossRef]

8. Mather, A.S. The forest transition. Area 1992, 24, 367-379.

9. Dewi, S.; van Noordwijk, M.; Zulkarnain, M.T.; Dwiputra, A.; Hyman, G.; Prabhu, R.; Nasi, R. Tropical forest-transition landscapes: A portfolio for studying people, tree crops and agro-ecological change in context. Int. J. Biodivers. Sci. Ecosyst. Serv. Manag. 2017, 13, 312-329. [CrossRef]

10. Singh, M.; Bhojvaid, P.; de Jong, W.; Ashraf, J.; Reddy, S. Forest transition and socio-economic development in India and their implications for forest transition theory. For. Policy Econ. 2017, 76, 65-71. [CrossRef]

11. Calaboni, A.; Tambosi, L.R.; Igari, A.T.; Farinaci, J.S.; Metzger, J.P.; Uriarte, M. The forest transition in São Paulo, Brazil. Ecol. Soc. 2018, 23, 7. [CrossRef]

12. Keenan, R.J.; Reams, G.A.; Achard, F.; de Freitas, J.V.; Grainger, A.; Lindquist, E. Dynamics of global forest area: Results from the FAO Global Forest Resources Assessment. For. Ecol. Manag. 2015, 352, 9-20. [CrossRef]

13. Wang, J.; Xin, L.; Wang, Y. Economic growth, government policies, and forest transition in China. Reg. Environ. Chang. 2019, 19, 1023-1033. [CrossRef]

14. Mather, A.S. Recent Asian Forest transitions in relation to forest transition theory. Int. For. Rev. 2007, 9, 491-502.

15. Meyfroidt, P.; Rudel, T.K.; Lambin, E.F. Forest transitions, trade, and the global displacement of land use. Proc. Natl. Acad. Sci. USA 2010, 107, 20917-20922. [CrossRef] [PubMed]

16. Wang, S.; Liu, C.; Wilson, B. Is China in a later stage of a U-shaped forest resource curve?-A re-examination of empirical evidence. For. Policy Econ. 2007, 10, 1-6. [CrossRef] 
17. Hu, A.G.; Shen, R.M.; Lang, X.J. Verification of the environmental Kuznets curve relationship between changes in China's forest resources and economic development: Based on provincial panel data from the second to the seventh national forest statistics. China Public Admin. Rev. 2013, 15, 61-75.

18. Batty, M. Thinking about Cities as Spatial Events. Environ. Plan. B Plan. Des. 2002, 29, 1-2. [CrossRef]

19. Li, X.; Yeh, A.G.-O. Analyzing spatial restructuring of land use patterns in a fast growing region using remote sensing and GIS. Landsc. Urban Plan. 2004, 69, 335-354. [CrossRef]

20. He, C.Y.; Li, J.W.; Zhang, X.L.; Liu, Z.F.; Zhang, D. Will rapid urban expansion in the drylands of northern China continue: A scenario analysis based on the Land Use Scenario Dynamics-urban model and the Shared Socioeconomic Pathways. J. Clean. Prod. 2017, 165, 57-69. [CrossRef]

21. Sun, Y.; Zhao, S.; Qu, W. Quantifying spatiotemporal patterns of urban expansion in three capital cities in Northeast China over the past three decades using satellite data sets. Environ. Earth Sci. 2015, 73, 7221-7235. [CrossRef]

22. Hassan, M. Mehedy, Monitoring land use/ land cover change, urban growth dynamics and landscape pattern analysis in five fastest urbanized cities in Bangladesh. Remote Sens. Appl. Soc. Environ. 2017, 7, 69-83.

23. Zhang, T.; Chen, S.S.; Li, G. Exploring the relationships between urban form metrics and the vegetation biomass loss under urban expansion in China. Environ. Plan. B 2020, 47, 363-380. [CrossRef]

24. Tang, J.; Wang, X. Analysis of the land use structure changes based on Lorenz curves. Environ. Monit. Assess. 2009, 151, 175-180. [CrossRef]

25. Gibbs, H.K.; Ruesch, A.S.; Achard, F.; Clayton, M.K.; Holmgren, P.; Ramankutty, N.; Foley, J.A. Tropical forests were the primary sources of new agricultural land in the 1980s and 1990s. Proc. Natl. Acad. Sci. USA 2010, 107, 16732-16737. [CrossRef]

26. Hansen, M.C.; Stehman, S.V.; Potapov, P.V. Quantification of global gross forest cover loss. Proc. Natl. Acad. Sci. USA 2010, 107, 8650-8655. [CrossRef] [PubMed]

27. Zhang, Y.; Shen, W.; Li, M.; Lv, Y. Assessing spatio-temporal changes in forest cover and fragmentation under urban expansion in Nanjing, eastern China, from long-term Landsat observations (1987-2017). Appl. Geogr. 2020, 117, 102190. [CrossRef]

28. Bonilla-Bedoya, S.; Mora, A.; Vaca, A.; Estrella, A.; Herrera, M.Á. Modelling the relationship between urban expansion processes and urban forest characteristics: An application to the Metropolitan District of Quito. Comput. Environ. Urban Syst. 2020, 79, 101420. [CrossRef]

29. Zhai, D.; Xu, J.; Dai, Z.; Schmidt-Vogt, D. Lost in transition: Forest transition and natural forest loss in tropical China. Plant Divers. 2017, 39, 149-153. [CrossRef]

30. Hall, J.M.; van Holt, T.; Daniels, A.E.; Balthazar, V.; Lambin, E.F. Trade-offs between tree cover, carbon storage and floristic biodiversity in reforesting landscapes. Landsc. Ecol. 2012, 27, 1135-1147. [CrossRef]

31. Sasaki, N.; Putz, F.E. Critical need for new definitions of "forest" and "forest degradation" in global climate change agreements. Conserv. Lett. 2009, 2, 226-232. [CrossRef]

32. Rudel, T.K.; Coomes, O.T.; Moran, E.; Achard, F.; Angelsen, A.; Xu, J.; Lambin, E. Forest transitions: Towards a global understanding of land use change. Glob. Environ. Chang. 2005, 15, 23-31. [CrossRef]

33. Redo, D.J.; Grau, H.R.; Aide, T.M.; Clark, M.L. Asymmetric forest transition driven by the interaction of socioeconomic development and environmental heterogeneity in Central America. Proc. Natl. Acad. Sci. USA 2012, 109, 8839-8844. [CrossRef]

34. Lambin, E.F.; Meyfroidt, P. Land use transitions: Socio-ecological feedback versus socio-economic change. Land Use Policy 2010, 27, 108-118. [CrossRef]

35. Michon, G.; de Foresta, H.; Levang, P.; Verdeaux, F. Domestic forests: A new paradigm for integrating local communities' forestry into tropical forest science. Ecol. Soc. 2007, 12. Available online: http://www.ecologyandsociety.org/vol12/iss2/art1/ (accessed on 20 May 2021). [CrossRef]

36. Foster, A.D.; Rosenzweig, M.R. Econoimc growth and the riese of forests. Q. J. Econ. 2003, 118, 601-637. [CrossRef]

37. Angelsen, A. Forest Cover Change in Space and Time: Combining the Von Thunen and Forest Transition Theories; The World Bank: Washington, DC, USA, 2007.

38. Klooster, D. Forest transitions in Mexico: Institutions and forests in a globalized countryside. Prof. Geogr. 2003, 55, $227-237$.

39. Bakker, M.M.; Govers, G.; van Doorn, A.; Quetier, F.; Chouvardas, D.; Rounsevell, M. The response of soil erosion and sediment export to land-use change in four areas of Europe: The importance of landscape pattern. Geomorphology 2008, 98, 213-226. [CrossRef]

40. Simwanda, M.; Murayama, Y. Spatiotemporal patterns of urban land use change in the rapidly growing city of Lusaka, Zambia: Implications for sustainable urban development. Sustain. Cities Soc. 2018, 39, 262-274. [CrossRef]

41. Jia, L.; Ma, Q.; Du, C.; Hu, G.; Shang, C. Rapid urbanization in a mountainous landscape: Patterns, drivers, and planning implications. Landsc. Ecol. 2020, 35, 2449-2469. [CrossRef]

42. Xu, Y.; Yu, L.; Peng, D.; Zhao, J.; Cheng, Y.; Liu, X.; Li, W.; Meng, R.; Xu, X.; Gong, P. Annual 30-m land use/land cover maps of China for 1980-2015 from the integration of AVHRR, MODIS and Landsat data using the BFAST. Sci. China Earth Sci. 2020, 63, 1390-1407. [CrossRef]

43. Liu, X.; Xun, L.; Xia, L.; Xu, X.; Wang, S. A future land use simulation model (FLUS) for simulating multiple land use scenarios by coupling human and natural effects. Landsc. Urban Plan. 2017, 168, 94-116. [CrossRef]

44. Huang, Z.; Wei, Y.D.; He, C.; Li, H. Urban land expansion under economic transition in China: A multi-level modeling analysis. Habitat Int. 2015, 47, 69-82. [CrossRef] 
45. Xian, S.; Li, L.; Qi, Z. Toward a sustainable urban expansion: A case study of Zhuhai, China. J. Clean. Prod. 2019, $230,276-285$. [CrossRef]

46. Iannace, G.; Ciaburro, G.; Trematerra, A. Wind Turbine Noise Prediction Using Random Forest Regression. Machines 2019, 7, 69. [CrossRef]

47. Rodriguez-Galiano, V.; Sanchez-Castillo, M.; Chica-Olmo, M.; Chica-Rivas, M. Machine learning predictive models for mineral prospectivity: An evaluation of neural networks, random forest, regression trees and support vector machines. Ore Geol. Rev. 2015, 71, 804-818. [CrossRef]

48. Niu, W.-J.; Feng, Z.-K.; Feng, B.-F.; Xu, Y.-S.; Min, Y.-W. Parallel computing and swarm intelligence based artificial intelligence model for multi-step-ahead hydrological time series prediction. Sustain. Cities Soc. 2021, 66, 102686. [CrossRef]

49. Rozelle, S.; Huang, J.; Benziger, V. Forest Exploitation and Protection in Reform China: Assessing the Impact of Policy, Tenure, and Economic Growth. Working Paper; Unpublished work. 2003.

50. Wang, S.; Cornelis van Kooten, G.; Wilson, B. Mosaic of reform: Forest policy in post-1978 China. Policy Econ 2004, 6, 71-83. [CrossRef]

51. Wenhua, L. Degradation and restoration of forest ecosystems in China. Ecol. Manag. 2004, 201, 33-41. [CrossRef] 